\title{
Two new species of Gelechiidae (Lepidoptera) from Korea, with some biological data including larval host plants
}

\author{
KYU-TEK PARK 1 , UN-HONG HEO ${ }^{2} \&$ BONG-KYU BYUN ${ }^{3 *}$ \\ ${ }^{1}$ Bio-Resource and Environmental Center, Incheon National University, Incheon, 22012, Republic of Korea. \\ ”ktpark02@gmail.com; (1) https://orcid.org/0000-0001-9933-4497 \\ 279-gil 88, Lotte Castle Beneluce, Sangam-ro, Gandong-gu, Seoul 714-1601, Republic of Korea. \\ ఏ" unhong53@naver.com; — https://orcid.org/0000-0002-2534-0605 \\ ${ }^{3}$ Department of Biological Science and Biotechnology, Hannam University, Daejeon, 34054, Republic of Korea. \\ "Dkbyun@hnu.kr; 10https://orcid.org/0000-0003-0393-6464 \\ *Corresponding author
}

\begin{abstract}
In this study, two new species of the family Gelechiidae are described from Korea. The new species are Teleiodes juglansivora Park \& Byun, sp. nov. and Encoplata najuensis Park \& Byun, sp. nov. For the new species, some biological data concerning on their larval food plants are given.
\end{abstract}

Key words: Asia, description, host plant, juglansivora, najuensis, taxonomy

\section{Introduction}

Since a comprehensive study of the family Gelechiidae in Korea was published by Park \& Ponomarenko (2007), reviewing 172 known species belonging to 69 genera, a total of 190 species have been recorded for the fauna of the Korean peninsula following the addition of 18 species (Park 2012, 2013; Park et al. 2014; Bae et al. 2014; Kim et al. 2014; Park \& Kim 2016; Kim \& Park 2017). Recently Park et al. (2020) described two additional new species and reported three species as new records from Korea.

In a recent survey on the larval host plants for the lepidopteran species in Korea carried by the second author since 2011, two new species of the genera Teleiodes Sattler, 1960 and Encolapta Meyrick, 1913 were discovered and are described. The first species, Teleiodes juglansivora Park \& Byun, sp. nov. is described based on reared specimens of which larvae feed on leaves of Juglans mandshurica Maxim. The second species, Encolapta najuensis Park \& Byun, sp. nov. is described based on the specimen of which matured larva was collected from Koelreuteria paniculata Laxm. and subsequently reared by providing fruits of the host.

\section{Material and methods}

Material examined herein is based on specimens whose larvae were collected from Juglans mandshurica Maxim. and Koelreuteria paniculata Laxm. in various localities in Korea by the second author. The collected larvae were reared in the room temperature, providing fresh leaves of the host plants under the room temperature keeping a proper humidity as similar as the natural condition until adults emerged. The moths were photographed with Cannon EOS 80D camera, and the genitalia slides were captured by Leica S8APO equipment, with an extension of Leica 10450317. Wingspan of the species was measured from the apex of the left wing to the apex of the right wing, and the color standard of adults follows Kornerup \& Wanscher (1978). The type specimens will be deposited in the National Institute of Biological Resources (NIBR), Incheon, Korea and in the Korea National Arboretum (KNA), Pocheon, Korea. 


\section{Taxonomic accounts}

\section{Genus Teleiodes Sattler, 1960}

Type species: Tinea vulgella [Dennis \& Schiffermüller], 1775.

The genus Teleiodes Sattler is mostly distributed in the Palaearctic region, with only a single species known from N. America. Ten species have been known in Europe (Huemer \& Karsholt 1999, 2020) and 10 species are known in Korea (Park \& Ponomarenko 2007). A wide range of various deciduous trees and bushes are known as their host plants.

Teleiodes juglansivora Park \& Byun, sp. nov.

LSIDurn:lsid:zoobank.org:act:D37F5AF2-71C8-48D4-BA62-059FBE25CCF6

(Figs 1A-G, 3A, B)

Type specimens. Holotype: + , Wonteo, Dongmyeon, Hongcheon, Gangwon Prov., 24.vii.2020 (larva collected on 9 vii 2020 from Juglans mandshurica, leg. UH Heo, gen. slide no. CIS-8152, deposited in NIBR.

Paratypes: 1 q, Mt. Gari-san, Hongcheon, 4.viii.2020 (larva collected on 15.vii.2020 from Juglans mandshurica, leg. UH Heo, gen slide no. CIS-8149; 1 q (abdomen missing), Miyaggol, Seoseok-myeon, Hongcheon, 11.viii.2020 (larva collected on 17.vii.2020) from the same host, leg, UH Heo, wing slide no. CIS-8176, deposited in KNA.

Diagnosis. The female genitalia are similar to those of the European species, Teleiodes luculella Hübner, [1813]) or T. flavimaculella (Herrich-Schäffer, 1854), but it can be distinguished from the latter by the following characters: 1) the ostium bursae is produced distally with convex apical margins dorsally and slightly convex ventrally in the new species, whereas that in the latter is deeply emarginated in apical margin; 2) the signum is cross-shaped, but that of the both species is rhomboid.

Description. Female (Figs 1A-D). Wingspan 14.0-14.5 mm.

Head: Dark brown dorsally. Antenna with scape elongated, thicker toward apex, dark fuscous; flagellum dark fuscous, with yellowish white annulations. Second segment of labial palpus thickened with appressed rough scales, grayish-white with fuscous bands at base, middle and before apex on outer surface, more grayish white on inner surface; $3^{\text {rd }}$ segment shorter than $2^{\text {nd }}$ segment, grayish white with dark fuscous broad bands at middle and before apex.

Thorax: Thorax and tegula dark fuscous. Hind tibia with orange-gray rough setae dorsally. Forewing lanceolate, with sharply produced apex; ground color dark fuscous, with yellowish-brownish indistinct spots irregularly presented; antemedian fascia black, oblique, narrow banded, arising from basal 1/5 of costa to 1/3 of inner margin; fringe concolorous with ground color; venation with $\mathrm{R}_{1}$ before middle of cell; distance between $\mathrm{R}_{1}$ and $\mathrm{R}_{2}$ at base about 1.5 times the distance between $\mathrm{R}_{2}$ and $\mathrm{R}_{3} ; \mathrm{R}_{3}$ free, arising from upper corner of cell; ; $\mathrm{R}_{4}$ and $\mathrm{R}_{5}$ stalked for about basal $2 / 5 ; R_{5}$ to costa; $M_{1}$ free from $R_{4+5} ; M_{2}$ present, nearer to $M_{3}$ at base; $M_{3}$ arising from lower corner of cell; $\mathrm{CuA}_{1}$ free, arising from near the lower corner of cell; $1 \mathrm{~A}+2 \mathrm{~A}$ long-forked in basal 1/3; cell weakly closed. Hind wing as broad as forewing, grayish white, venation with $\mathrm{M}_{1}$ approximated to Rs; $\mathrm{M}_{2}$ present, slightly arched before middle; fringe concolorous with ground color; venation with $\mathrm{M}_{3}$ arising from lower corner of cell; $\mathrm{CuA} \mathrm{A}_{1}$ near to $\mathrm{M}_{3}$ at base; $\mathrm{CuA}_{2}$ arising from beyond 2/3; cell closed.

Female genitalia (Figs 1F, G): Apophyses anteriores thick, long, about 1/2 the length of apophyses posteriors. Ostium bursae hood-shaped, heavily sclerotized; dorsal plate produced apically, strongly convex; ventral plate slightly convex apically. Antrum short, cylindrical, membranous, extending to about 1/3 the length of ostium bursae. Ductus bursae narrow, about 1.5 times the length of corpus bursae; broader toward corpus bursae. Ductus seminalis arising from distal 1/3 of ductus bursae, narrow, about 1/4 the width of ductus bursae. Corpus bursae large, ovate; signum cross-shaped, with elongated upper and lower plates serrate along lateral margins, and with a deep, broad transverse burrow centrally.

Male unknown. 

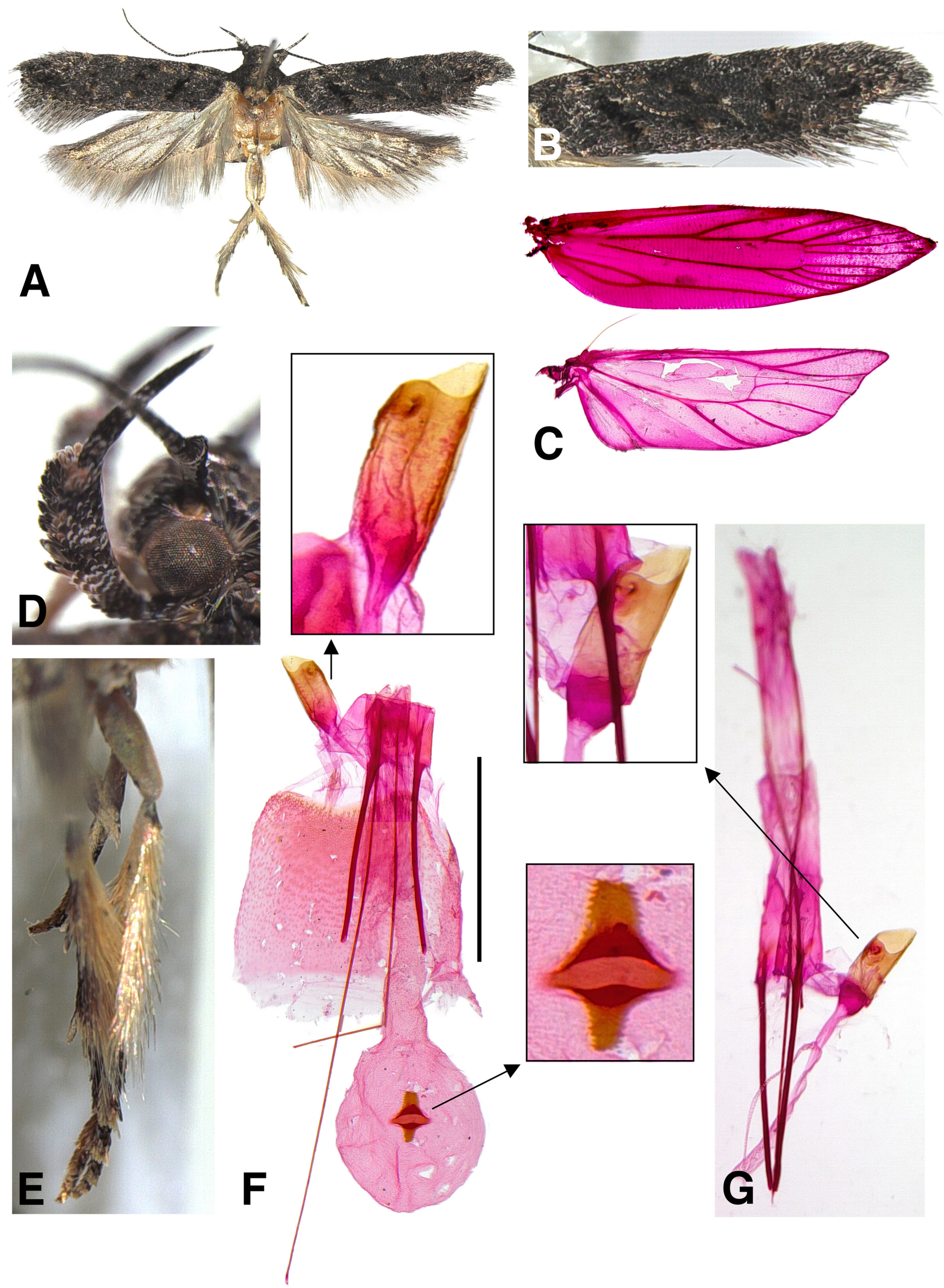

FIGURE 1. Teleiodes juglansivora Park \& Byun, sp. nov. A, adult, holotype; B, ditto, close-up right forewing; C, under surface of wings, with name of veins; D, head and labial palpus, in lateral view; E, hind tibia, paratype; F, female genitalia, holotype, gen slide no. CIS-8152; F, ditto, paratype, gen slide no, CIS-8149. Scale bar for the genitalia and aedeagus: $1.0 \mathrm{~mm}$. 
Biology. Three larvae feeding on leaves of Juglans mandshurica were collected on 9.vii, 15.vii, and 17.vii.2020, and reared while providing fresh leaves of the host plant. The moths emerged on 24.vii and 4.viii.2020. It is the first record that the plant species of Juglans serves as a host for the Teleiodes species of moths.

Distribution. Korea.

Etymology. The species is derived from the genus name, Juglans, of the host plant.

\section{Genus Encolapta Meyrick, 1913}

Type species: Encolapta metorcha Meyrick, 1913.

= Homoshelas Meyrick, 1935

= Chelophoba Meyrick, 1935

= Homochelas Clarke, 1969

The genus Encolapta Meyrick, 1913 is superficially similar to Hypatima Hübner [1825], but it can be separated by the abdominal tergite VIII with a simple sclerotized, banded or semi-elliptical plate and the valvella without apical thorn in male. The genus comprises 17 species, mostly distributed in Asia (Yang \& Li 2016). In Korea, three species of the genus Encolapta have been known: E. catarina (Ponomarenko, 1994), E. tegulifera (Meyrick, 1932). and $T$. subtegulifera (Ponomarenko, 1994).

\section{Encolapta najuensis Park \& Byun, sp. nov.}

LSIDurn:1sid:zoobank.org:pub:E963A96C-1BEC-472B-AAA6-53F16DBC6376

(Figs 2A-F, 3C)

Type specimen. Holotype: ${ }^{\Uparrow}$, Naju, Naju Forest Res. Institute, Jeonnam Prov., 9.vi.2019, gen. slide no. CIS-8150, deposited in NIBR.

Diagnosis. This species is superficially similar to E. marginans (Li \& Zheng, 1998) described from Shaanxi Prov., China, but it can be distinguished from the latter by the male genital characters as follows (Fig. 2C, F): 1) the uncus is broadened distally (Figs 2C-(1)), whereas in E. marginans it is nearly parallel-sided (Fig. 2F); 2) the gnathos is larger and stronger than that of E. marginans (Fig. 2C-(2); 3) the basal protrusion on inner margin of valva is much larger in the new species (Fig. 2C-(3)); 4) the saccus is slender, nearly parallel-sided (Fig. 2C-(4)), whereas in E. marginans, it is dilated distally, nearly clavate.

Description. Male. Wingspan $14.0 \mathrm{~mm}$.

Head: Grayish white to orange gray, speckled with brownish scales dorsally. Antenna with scape elongated, dark fuscous dorsally, yellowish white ventrally; flagellum dark fuscous dorsally, yellowish white ventrally. Second segment of labial palpus with triangular scale tuft ventrally, dark brown speckled with grayish white scales on outer surface, paler on inner surface; $3^{\text {rd }}$ segment rather stout, longer than $2^{\text {nd }}$ segment, grayish white, with dark-brown bands at base, middle, and beyond $2 / 3$.

Thorax: Thorax and tegula orange gray ventrally. Hind tibia with yellowish-white rough setae dorsally, dark brown ventrally. Forewing lanceolate, with sharply produced apex; ground color dark brown, with blackish short streaks irregularly scattered; 5-6 yellowish-white small patches along costa from near base prior to apex; fringe concolorous with ground color; venation with $\mathrm{R}_{3}$ free, arising from upper corner of cell; $\mathrm{R}_{4}$ and $\mathrm{R}_{5}$ stalked for about basal $1 / 3 ; R_{5}$ to costa; $M_{1}$ free from $R_{4+5} ; M_{2}$ present, nearer to $M_{3}$ at base; $M_{3}$ arising from lower corner of cell; $\mathrm{CuA}_{1}$ free, arising from near the lower corner of cell. Hind wing grayish white; venation with $\mathrm{M}_{3}$ and $\mathrm{CuA}$ connate; fringe concolorous. Abdomen: Spinous zones on tergites absent; sternite VIII deeply emarginated at middle on caudal margin.

Male genitalia (Figs 2C, D): Uncus oblong, dilated distally with round apex, separated from basal sclerite. Gnathos strong, longer than uncus, heavily sclerotized, curved medially, with sharply pointed apex. Tegumen weakly sclerotized. Valva narrowed in basal $3 / 5$, with semi-ovate membranous protrusion at base on ventral margin; cucullus significantly dilated distally, with round apex, densely setose, Valvella slender, about half the length of valva, sclerotized in posterior half. Juxta with large triangular latero-caudal plates, bearing strong along margins. 


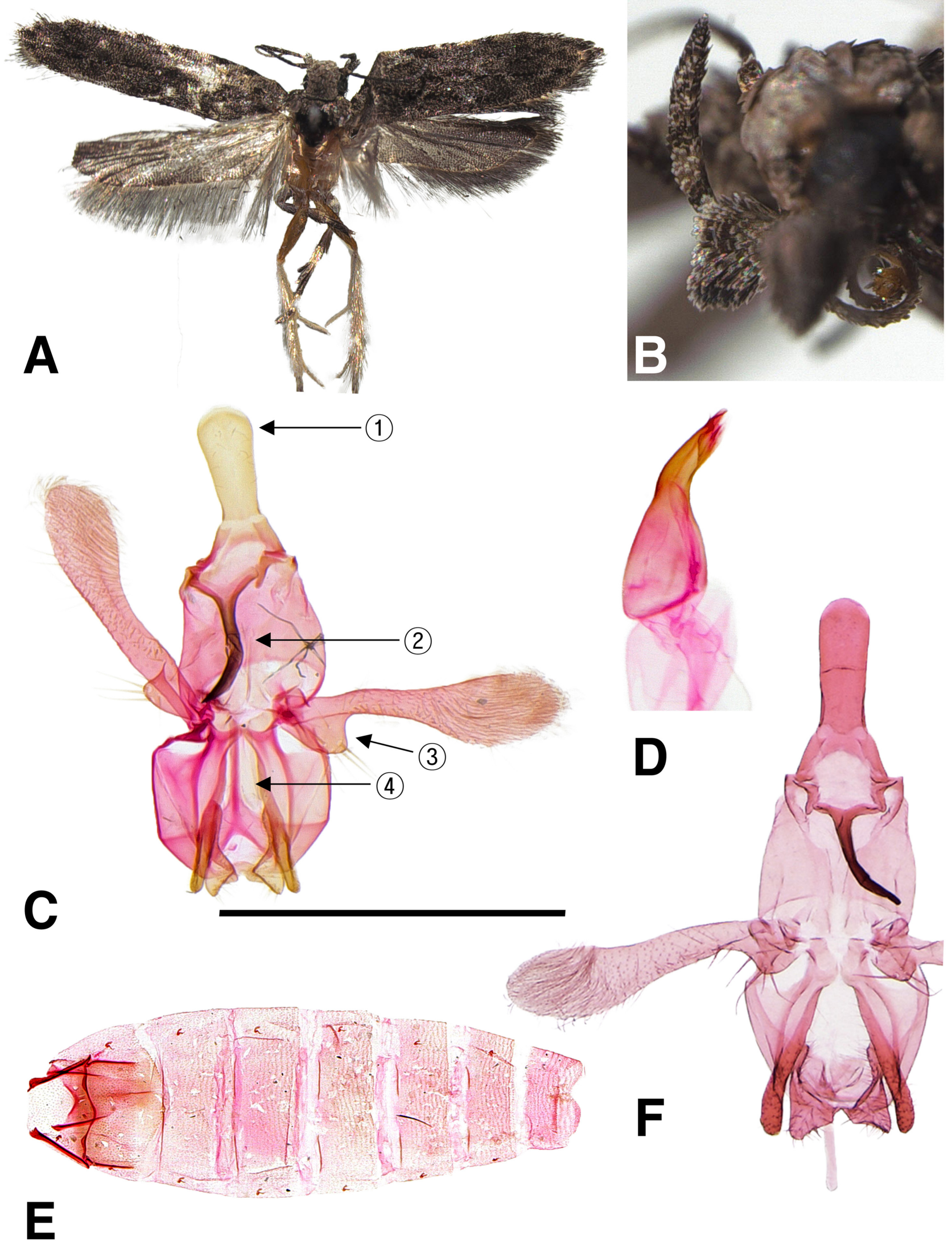

FIGURE 2. Encolapta najuensis Park \& Byun, sp. nov. A, adult, holotype; B, ditto, labial palpus; C, male genitalia, gen. slide. No. CIS-8150; D, ditto, aedeagus; E, abdomen. Scale bar for the genitalia and aedeagus: $1.0 \mathrm{~mm}$. 
Vinculum with triangular anterior plate, bearing setae. Saccus slender, as long as uncus. Aedeagus globular in basal $3 / 5$, then narrowed distally with two small spines apically; cornutus absent. Abdomen lacking spinose zones.

Biology. Little is known about the biology of Encolapta species. E. tegulifera (Meyrick) is only a single species whose larval host plants Quercus sp. has been known (Inoue et al. 1982, Li 2002). The two matured larvae were collected under the trees of Koelreuteria paniculata Laxm on 05.ix.2019, that were dropping down with silk-net. The larvae are about $10 \mathrm{~mm}$ in body length, the head capsule is black, with purplish brown lines at both sides on the body. It is considered that the larva is probably feeding on fruits of the host plant, since it was observed that larvae made silk-nets around the fruit of Koelreuteria paniculata Laxm, and one pupated inside the hull of the fruit after two days of rearing in laboratory conditions. Thus, the larvae of the new species were kept with the fruits that provided them a shelter for the pupation. The first moth has emerged on 9.vi.2020, but second larva failed to pupate. The larval habits have not been observed and documented, but it is no doubt that the larva is associated with the fruit of Koelreuteria paniculata.

Distribution. Korea.

Etymology. The species name is derived from the type locality, "Naju", Korea.
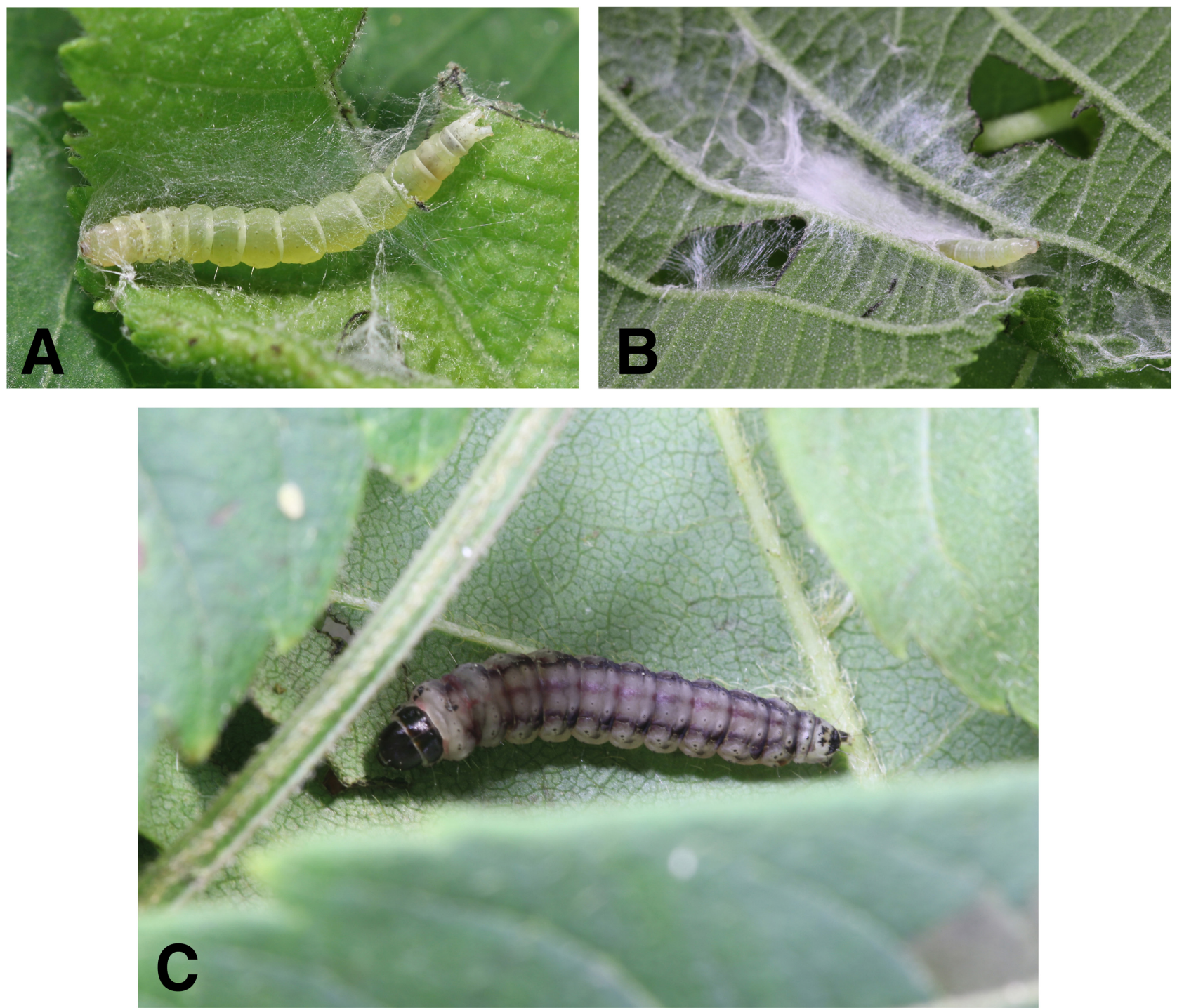

FIGURE 3. Larvae. A, matured larva of Teleiodes juglansivora Park \& Byun, sp. nov.; B, ditto, prepupation in the silk-net; C, matured larva of Encolapta najuensis Park \& Byun, sp. nov.

\section{Acknowledgements}

This work was supported by a grant from the National Institute of Biological Resources (NIBR), funded by the 
Ministry of Environment (MOE) of the Republic of Korea (NIBR 202102204) and R\&D Program for Forest Science Technology (Project No. FTIS 2017042B10-2123-CA01) provided by Korea Forest Service (Korea Forestry Promotion Institute). We are indebted to Dr. Jurate De Prins, who made some corrections and helpful comments to improve this manuscript. and Dr. Da-Som Kim, Natural History Museum, Hannam University for her help in the preparation of plates.

\section{References}

Bae, Y.S., Lee, B.W. \& Park, K.T. (2014) Gelechiid fauna of Baengnyeongdo, Daecheongdo, and Yeonpyeongdo in the West Sea near North Korea, with description of two new species (Lepidoptera, Gelechioidea). Entomological Research, 44, 17-22. https://doi.org/10.1111/1748-5967.12045

Clarke, J.F.G. (1969) Catalogue of the Type Specimens of Microlepidoptera in the British Museum (Natural History) described by Edward Meyrick. Vol. 7. Natural History Museum, London, 531 pp.

Denis, J.N.C.M. \& Schiffermüller, I. (1775) Ankündung eines systematischen Werkes von den Schmetterlingen der Wienergegend. Bernard, Vienna, $322 \mathrm{pp}$.

Herrich-Schäffer, G.A.W. (1854) Systematische Bearbeitung der Schmetterlinge von Europa, zugleich als Text, Revision und Supplement zu J. Hübner's Sammlung europäischer Schmetterlinge, Die Schaben und Federmotten. Die Tagfalter, Regensburg, 64, 121-168.

Hübner, J. ([1825]) Verzeichniss bekannter Schmettlinge. bey dem Verfasser zu Finden. Verlag J. Hübner, Ausburg, pp. 353431.

Hübner, J. (1810-1813) Sammlung europäischer Schmetterlinge. VIII. Tineae-Schaben (,,Sechste Band“ - part). [8]. Verlag J. Hübner, Ausburg, pls. 45-63, f. 308-426.

Huemer, P. \& Karsholt, O. (1999) Microlepidoptera of Europe. Vol. 3. Gelechiidae I. (Gelechiinae: Teleiodini, Gelechiini). Apollo Books, Stenstrup, 356 pp.

Huemer, P. \& Karsholt, O. (2020) Commented checklist of European Gelechiidae (Lepidoptera). Zookeys, 921, 65-140. https://doi.org/10.3897/zookeys.921.49197

Inoue, H., Sugi, S., Kuroko, H., Moriuti, S., Kawabe, A. \& Owada, M. (1982) Moths of Japan. Vols. 1 \& 2. Kodansha, Tokyo, 966 pp. (text) \& 552 pp. (plates and Synonymic Catalogue)

Kim, M.Y., Byun, B.K. \& Park, K.T. (2014) Four species of micromoths new to Korea (Lepidoptera: Elachistidae, Gelechiidae, Coleophoridae). Journal of Asia Pacific Entomology, 7, 258-261.

https://doi.org/10.1016/j.japb.2014.06.002

Kim, M.Y. \& Park, K.T. (2017) Three species of Gelechiidae (Lepidoptera: Gelechioidea) new to Korea. Korean Joural of Applied Entomology, 56, 93-96. https://doi.org/10.5656/KSAE.2017.02.1.090

Kornerup, A. \& Wanscher, J.H. (1978) Methuen Handbook of Colour. $3^{\text {rd }}$ Edition. Methuen and Co. Ltd., London, 252 pp.

Li, H.H. (2002) The Gelechiidae of China (I) (Lepidoptera: Gelechioidea). Nankai University Press, Tianjin, 538 pp.

Li, H.H. \& Zheng, Z.M. (1998) Notes on Hypatima and Homoshelas (Lepidoptera: Gelechiidae) from the mainland of China, with descriptions of new species. Entomotaxonomia, 20 (2), 143-149.

Meyrick, E. (1913) Meyrick, E. (1913) Descriptions of Indian micro-lepidoptera (16-17). Journal of the Bombay Natural History Society, 22 (1), 160-182.

Meyrick, E. (1932) Exotic Microlepidoptera. Vol. 4. Marlborough, London, 685 pp.

Meyrick, E. (1935) List of Microlepidoptera of Chekiang, Kiangsu and Hunan. In: Caradja, A. \& Meyrick, E. (Eds.), Materialien zu einer Microlepidopteren-Fauna der chinensischen Provinzen Kiangsu, Chekiang und Hunan. Friedländer, Berlin, pp. 44-96

Park, K.T. \& Ponomarenko, M.G. (2007) Gelechiidae of the Korean Peninsula and adjacent territories (Lepidoptera). In: Park, K.T. (Ed.), Insect of Korea. Vol. 12. Jeunghengsa, Seoul, pp. 1-312.

Park, K.T. (2012) Gelechiidae I (Insecta: Lepidoptera). In: Insect of Korea. Vol. 16 (6). National Institute of Biological Resources, Ministry of Environment, Incheon, $200 \mathrm{pp}$.

Park, K.T. (2013) Gelechiidae II (Insecta: Lepidoptera). In: Insect of Korea. Vol. 16 (9). National Institute of Biological Resources, Ministry of Environment, Incheon, 143 pp.

Park, K.T., Kim, M.Y. \& Byun, B.K. (2014) Gelechiidae collected from Is. Ulleung-do in the East Sea, reporting a newly recorded species from Korea and an unknown species. Korean Journal of Applied Entomology, 53, 97-101. https://doi.org/10.5656/KSAE.2014.01.1.083

Park, K.T. \& Kim, M.Y. (2016) Two new species of the family Gelechiidae (Lepidoptera, Gelechioidea) from Korea. Oriental Insects, 50, 171-177. https://doi.org/10.1080/00305316.2016.1230527

Park, K.T., Heo, U.H. \& Byun, B.K. (2020) Two new species and three unrecorded species of Gelechiidae (Lepidoptera: Gelechioidea) from Korea, with biological data including larval host plants. Journal of Asia-Pacific Biodiversity, 13 (4), 605-612. 
https://doi.org/10.1016/j.japb.2020.09.014

Ponomarenko, M.G. (1994) Two new species of the genus Dactylethrella Fletcher (Lepidoptera, Gelechiidae) from Russian Far East. Japan Heterocerists' Journal, 176, 7-9.

Sattler, K. (1960) Generische Gruppierung der europaischen Arten der Sammelgattung Gelechia (Lepidoptera, Gelechiidae). Deutsche entomologische Zeitschrift, 7 (1-2), 10-118.

https://doi.org/10.1002/mmnd.4800070103

Yang, M. \& Li, H.H. (2016) Review of the genus Encolapta Meyrick, 1913 (Lepidoptera: Gelechiidae: Chelariini) from China, with description of six new species. Zootaxa, 4193 (2), 201-227.

https://doi.org/10.11646/zootaxa.4193.2.1 